\title{
ДО РОЗМЕЖУВАННЯ ПОНЯТЬ «ЯКІСНА» ТА «ЕЛІТАРНА» ПРЕСА (НА ПРИКЛАДІ США)
}

\author{
Наталія Михайлів \\ Львівський національний університет імені Івана Франка, \\ вул. Генерала Чупринки, 49, 79044, Львів, Україна, \\ e-mail: ozerna.n9@gmail.com
}

У статті на прикладі історичного процесу становлення та сучасного функціонування преси у США зроблено спробу розмежувати поняття «елітарна преса» та «якісна преса», з'ясовано сутність кожного з цих понять, виокремлено ознаки «якісної» та «елітарної» преси, виявлено закономірності в уживанні цих понять, напрацьовано параметри розмежування якісної та елітарної преси та запропоновано визначення кожної 3 них. 3 цією метою на основі праць учених США проаналізовано генезу елітарної преси у США, виявлено, що чільне місце у ній посідає журнал, запропоновано класифікацію елітарної і якісної преси на основі читацького критерію.

Ключові слова: елітарна преса, якісна преса, еліта, якісність, аудиторія, журнал.

В одвічному прагненні до благополуччя суспільство та індивід потребують визначеності, що досягається за двома напрямами: інтелектуалізацією - по-перше, й плеканням правдивих цінностей - по-друге. Одним із засобів акумуляції обох є категорія преси, котру йменують «якісною». Вартий наслідування історичний досвід творення видань цього типу мають США, де в XIX-XX століттях якість зробила пресу успішною, а її читання - престижним. Положення цієї статті дозволять удосконалити практику національних видань 3 претензією на якісність, збагатити творців цих видань теоретичними знаннями про «якісну» та «елітарну» пресу, відмінності між останніми й створити підвалини для утвердження українських елітарних видань.

Чимало наукових праць містять термін «якісна преса», однак спосіб його співвідношення з терміном «елітарна преса» вчені не уточнюють, нерідко вживаючи їх як тотожні. Мета статті в тому, щоб виявити відмінності в поняттях «якісна преса» та «елітарна преса» на прикладі становлення й сучасного функціонування преси в Сполучених Штатах Америки. Метою обумовлені завдання: здійснити аналіз джерельної бази, присвяченої елітарній та якісній пресі Сполучених Штатів Америки; прослідкувати генезу преси США, з'ясувати місце та роль якісної та елітарної преси в її загально-історичному масиві; виявити критерії для відмежування елітарної і якісної преси на прикладі становлення і функціонування преси у США; запропонувати авторське визначення «елітарної преси» та «якісної преси».

(C) Михайлів Н., 2018 
У спробі термінологічного розмежування автор спирається на праці таких дослідників як О. Биков, Дж. П. Вуд, М. Житарюк, Й. Лось, Ф. Л. Мотт, Т. Петерсон, О. Попова, В. Смеюха, Ф. Хадсон.

Відмежування «якісної» преси від «елітарної» знаходимо у монографії М. Житарюка «Соціокультурна модель журналістики: традиції і новаторство», де якісну пресу автор ототожнює з опінієтворчою, серйозною пресою, пресою думок, а елітарну - 3 національною, соціально відповідальною пресою [2, с.108]. Пов'язаність елітарної преси й національно зорієнтованої преси закономірна, адже, як зауважує М. Пірен, «справжньою елітою в суспільстві завжди виступає еліта інтелектуально-культурно-духовна, яка покликана генерувати нові ідеї, ставити та вирішувати розумово-життєві питання» $[8$, с.38]. Утвердження духовності, культури народу, у свою чергу, не є можливим без глибокого національного стержня, котрий покликана плекати свідома частина суспільства.

Корінь слова «елітарний» - «еліта», насамперед містить вказівку на суб'єкт. На думку дослідниці елітарних ЗМІ О. Попової, виділ елітарної преси пов'язаний із соціальною структурою суспільства, його сегментацією й жорсткою структурованістю. Наявність же сегмента структури передбачає й наявність засобів комунікації для нього [9, с.28-29]. На суб’єктному аспекті елітарної преси зупиняється й український дослідник преси Б. Черняков, виокремлюючи «елітарні видання», що «мали набагато вужче коло поширення і аудиторію, котру становила панівна високостанова i адміністративна верхівка, а також читачі, що одержали відносно високу загальну чи спеціальну освіту» [14, с.81]. 3 цитованого випливає, що аудиторію елітарних видань утворюють дві категорії читачів: панівна верхівка - еліта - по-перше, й освічені, заможні громадяни, котрі до неї не увійшли, - по-друге.

Зупинимось на тлумаченні поняття «еліта». Філософський енциклопедичний словник визначає еліту як групу осіб, яка займає провідне або керівне становище у будь-якій галузі людської діяльності: політичній, економічній, науковій, культурній, інтелектуальній тощо. Згідно консервативної соціальної філософії, котра складає основу елітарних концепцій, на вершині вертикально організованих структур перебувають охоронці цінностей даної культури, організатори, творчі особистості, а на нижчих шаблях - виконавці [15, с.194]. Еліта, - значиться у словнику іншомовних слів, - про людей, що виділяються серед інших своїм суспільним становищем, розумом, здібностями і т. ін.; привілейована верхівка суспільства або якої-небудь його частини; елітарний - вибраний, доступний не для всіх, призначений для еліти; кращий, добірний [10, с.213]. До елітарної культури в теорії останньої відносять культуру «духовної аристократії», висококультурних представників груп суспільства, субкультур, привілейованих груп суспільства, що характеризуються принциповою закритістю, ціннісно-змістовою самодостаністю, протиставленій масовій в широкому сенсі культурі [12, с.578], наділяючи її адресністю. Отже, термін «елітарна преса» містить вказівку на цільову аудиторію цієї преси, котра $є$ самодостатньою з фінансового та ціннісно-змістового погляду, відзначається високим суспільним становищем, непересічним інтелектом та, висуваючи високі вимоги до своєї діяльності та атрибутів життя, відповідно, ставить такі ж й до якості преси, котру читає.

Відомі дослідники преси США П. Вуд, Ф.Л. Мотт, Т. Петерсон, Ф. Хадсон [16$18,20]$ одностайні у тому, що перша преса США наслідувала британську модель просвітницьких журналів-есе, стосувалася літератури, мистецтва, манер, подорожей та 
історії, була недоступною масовому читачеві, розраховувались на освічену аудиторію $з$ рівнем достатку вищим за середній. «Еліта, котра прибула в Сполучені Штати Америки з Англії, - писав відомий американський дослідник преси Ф. Л. Мотт, формувала газети і журнали за взірцем публікацій, котрі вона отримувала з дому, а популярні суботні та недільні збірники за змістом були більш схожими на журнали, аніж на газети, процвітали за рахунок історій, моральних есеїв та віршів, із певною домішкою дорожніх заміток, науки, мистецтва» [17, с.319-320]. На схожість перших газет і журналів XIX століття звернув увагу Ф. Хадсон, віднісши «Ледіс мегезін» до власне журналів та зауваживши, що поглинуті жіночою модою «Мадам деморестс мегезін», «Ле моуд», «Ле фоллет» та «Базаар» не були газетами у суворому розумінні [16, с.52]. Положення з досліджень преси США ученими цієї ж країни свідчать,

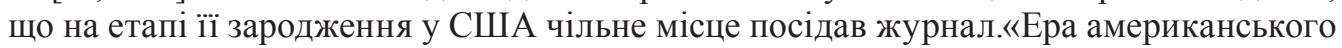
журналу, - відзначає відомий дослідник журналів США Дж. П. Вуд, - розпочалася 3 «Гоудіс Лейдіс Бук», котрий багато зробив для побудови ідеї американської жінки щодо того, якою вона (жінка - примітка наша. - Н. М.) $\epsilon$, як повинна діяти і на якому ставленні до себе наполягати [20, с.54]. В фундаментальній праці «Журнали у двадцятому столітті» до якісних журналів США кінця XIX століття Т. Петерсон, відносив «Сенчурі», «Харперс» та «Скрайбнерс», називав їх «дорогою вишуканістю», характеризував аудиторію цих видань як «читачів змісту». «За художньою та літературною якістю, об’ємом ... ці три журнали були лідерами серед загальної місячної періодики. Їх редактори працювали не для великих мас населення..., але до панства, яке володіло засобами» [18, с.3-5, 29]. Перші жіночі видання США розраховувались на ерудовану, свідому глобальних проблем читачку, робили внесок у побудову концепції американської жінки, іiї світогляд, наділялися художньою спрямованістю й престижем, та, сповнені атрибутів розкішного життя, допомагали заможним жінками внести у нього максимум естетизму.

Наведене дозволяє дійти таких висновків. По-перше, рафінованому змістові перших елітарних видань США кореспондувала відповідна аудиторія (еліта), по-друге, чільне у ній місце посідали гендерно марковані - жіночі, видання, й, по-третє, елітарну пресу асоціюють передусім з журнальною періодикою. Виходячи 3 періодичністю один раз на місяць, замість висвітлення злободенних питань журнал може дозволити собі зосередитися на всебічному аналізі політичної, економічної, мистецької дійсності, літературі тощо. Завдання журналів, - як зазначають автори посібника «Типологія періодичних видань», - подати факти не в спалахах першого знайомства, а в світлі роздумів чи творчого перетворення, а «відставання» використовується як перевага: «зупинитися і оглянутися» й, остигнувши від вражень хвилини, осмислити подію або ж захопити читача образною картиною» [13, с.79]. У цьому зв'язку періодичність виходу видання виступає чинником здійснюваного на його сторінках аналізу, осмислення, інтерпретації явищ довколишнього світу, надання їм образності.

3 плином часу та змінами в суспільному виробництві зазнавала змін і елітарна преса. Наприкінці XIX - на початку XX століття газети й журнали стають доступними широкому загалу США й перестають бути лише надбанням обраних. Коли читання стає популярним й поширеним способом проведення часу, елітарний характер преси США, - пише В. Смеюха, - відображався на системі періодики, що представляла обмежену кількість типів видань; на тематиці і стилістичних характеристиках публікацій, розрахованих на високоосвічених читачів [11, с.77-80]. Попри суспільні 
трансформації елітарний сегмент соціальної структури продовжує висувати запит на відповідну пресу. Подаючи коротку характеристику сучасних провідних видань США журнал «Атлантік Манслі» Й. Лось визначає у якості «елітарного інтелектуального місячника» [5, с.285]. Читачі журналу «Портфоліо»-високоосвічені, успішні й часто подорожують. Вони віддають перевагу гольфу, тенісу і яхтингу. «Портфоліо» залучає найкращих журналістів та пропонує достойні світлини. Публікації стосуються персоналій, моди, бізнесу, дизайну інтер'єру, відпочинку, мистецької сцени тощо [19]. 3 часу їх заснування ознаками жіночих журналів «Харперс Базар» та «Вог» були заможний вигляд, утаємниченість в моді, іiі вишуканість, новизна та дороговизна [20, с.124-125], кристалізуючи їх тип видань для жінок, котрі живуть в добробуті, мають прогресивний світогляд та прагнуть наповнити власні будні вишуканістю.

Лідерство перших журналів розкоші серед періодики свідчить про значний запит на них з боку читацької аудиторії, причому інтерес до елітарної преси виявляють не лише ті, хто посідає високі соціальні сходинки. 3 часу заснування перших журналів цього виду атрибути життя заможних громадян, яке вона віддзеркалює, прагнуть привнести у своє і менш забезпечені з них. Пошук й перцепція окремими представниками незаможних суспільних верств атрибутів добре організованого, наповненого благами буття Х. Ортега-і-Гасет обгрунтовує особливістю розуміння однією з груп людей «нового» мистецтва, яка полягає в наділеності органом розуміння, наявність якого заперечується в іншої. Саме так, на думку вченого, можна описати механізм засвоєння елітарних цінностей, «звернених до обдарованої меншості», котрий відбувається поза належністю до певного соціально-економічного класу [7]. Можемо висновувати, що елітарні видання - орієнтир для двох категорій читачів: тих, котрі перебувають на вершині вертикально організованих суспільних структур (1) та тих, що прагнуть до перцепції елітарних цінностей попри неналежність до цієї категорії суспільства (2). До ознак елітарної преси США, таким чином, належать: становлення під впливом англійської еліти, мистецький ухил, великий запит на неї з боку елітарного сегмента соціальної структури, значна увага до стилю життя та вишуканих його атрибутів, велика питома вага жіночої елітарної преси.

В той час коли «елітарний» указує на суб'єкт, слово «якісний» походить від іменника «якість» і означає характеристику об’єкта (преси). Якість (цінність) інформації - одна $з$ основних вимог до діяльності журналістики у справі забезпечення нею реальної обізнаності суспільства про основні події сучасності, зменшення стану невпевненості й невизначеності читацької аудиторії [4, с.302]. Чинниками, які визначають якісність засобу масової інформації є добре продумана концепція видання, відповідність мови ЗМІ і стилю, манери викладу інформації літературним нормам, застосування публіцистичного стилю, вдале оформлення, охоплюваність широкого географічного загалу, розкуповуваність, рейтингові позиції, високопрофесійний авторський склад, відносна фінансова і політична незалежність [3]. Якісній пресі притаманні аналітичність в підході до подій, зваженість оцінок, спокійний тон публікацій, а головне - надійність фактів та думок, - висновує С. Корконосенко [7, с.95]. В сучасному світі людина постає об'єктом неминучого політичного, економічного й психологічного впливу й щораз то більшої ваги набуває її уміння з'ясувати для себе, де істинне знання, а де - хиби, відсіяти друге та, зменшивши/ усунувши невизначеність, прояснити світ, в якому живе. Остання, у свою чергу, елімінується накопичен- 
ням, аналізом та синтезом інформації. Соціальним інститутом, покликаним реалізувати цю функцію, є якісна преса. На думку О. Бикова, ознаками якісної преси у США володіють «Нью-Йорк Таймс», «Уол-Стріт Джорнал», а також «Вашингтон Пост», «Лос-Анжелес Таймс», «Чікаго Трібюн» та інші. Ці ЗМІ, - продовжує вчений, - призначені для певної аудиторії - політиків, представників ділових кіл, тих, хто володіє політичною та економічною владою, слідкує за розвитком економічних та політичних подій [1]. Логічно випливає розгалуження аудиторії якісної преси на ділові кола (1) і тих, хто слідкує за розвитком політично, економічно, соціально значущих подій, хоча й не приймає управлінських рішень (2). Примітно також, що як приклади якісної преси дослідники наводять щоденні видання (газети), а також тижневики. Так, щоденну газету «Нью-Йорк Таймс» Й. Лось характеризує як «одну з найповажніших і найвпливовіших газет у світі»; «Тайм» - тижневик, «одне 3 найголовніших опінієтворчих видань у світі»; «Нешинел Рів’ю» - «консервативний, аналітичний, опінієтворчий тижневик» [5, с.283-284]. Емпіричний аналіз перелічених видань засвідчує: увагу в них акцентовано передусім на соціальних і політичних проблемах й можливих шляхах їх подолання.

Наведене дозволяє зробити такі висновки. По-перше - якісну пресу складають у першу чергу щоденні та тижневі видання; по-друге - характерною їх тематикою $€$ загальнополітична; по-третє - поряд 3 особами, що включені до політичного та бізнесового життя США і послуговуються якісною пресою з метою прийняття вдалих управлінських рішень, до читачів цієї преси належить також високоосвічена, інтелектуальна частина суспільства, ті, хто виявляє цікавість до економічних, політичних подій країни і світу, не перебуваючи водночас на їх сцені. Схематично категорії читачів якісної та елітарної преси наведено у Схемі 1.

\section{Аудиторія якісної та елітарної преси (на прикладі США)}

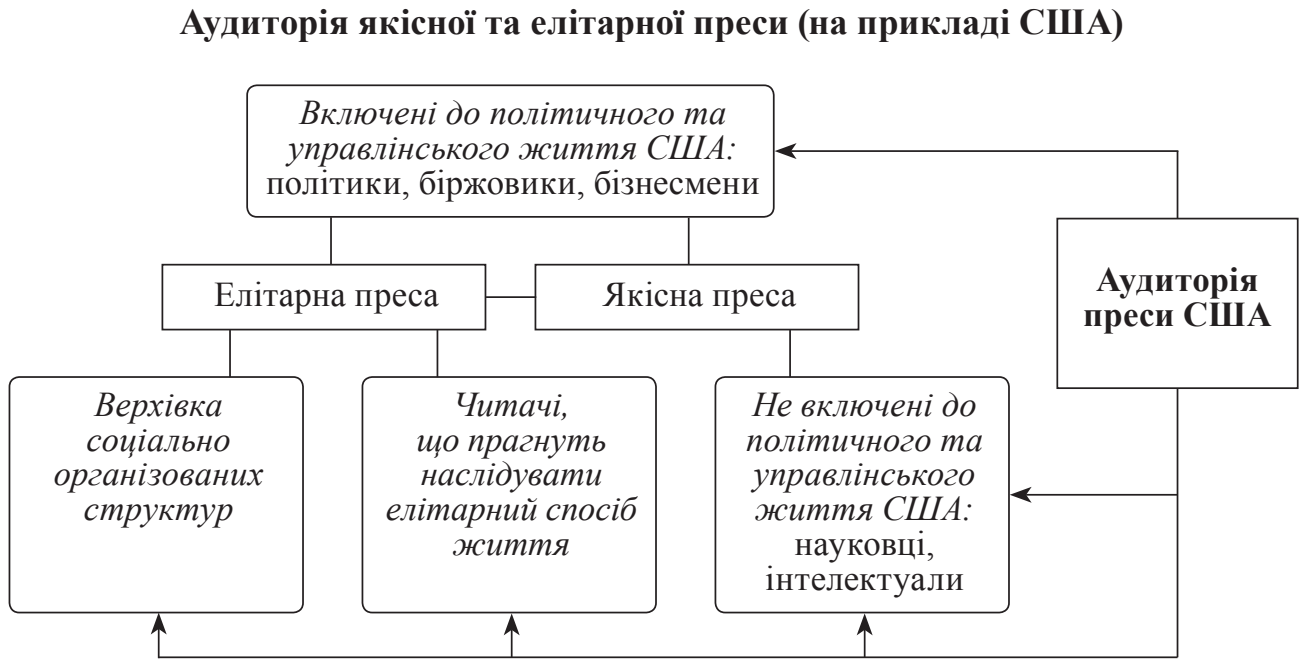

Високопрофесійний авторський склад - залучення провідних журналістів та фотографів з метою створення фахових матеріалів, стриманий мовний стиль, престиж залишаються спільними ознаками якісної та елітарної преси. Елітарні 
видання висувають високі вимоги до своєї якості, що прослідковуємо на прикладі американського журналу «Портфоліо». В означеному контексті не буде помилкою назвати примірники елітарних видань «якісними». Разом із цим, дослідження понять «якісна» та «елітарна» преса, здійснене на прикладі преси США, демонструє існування між ними відмінностей, котрі подано у Таблиці 1.

Таблиця 1

\section{Відмінності між «якісною пресою» та «елітарною пресою» (на прикладі США)}

\begin{tabular}{|c|c|c|c|}
\hline $\begin{array}{l}\text { № } \\
\text { N/П } \\
\end{array}$ & $\begin{array}{c}\text { Параметр } \\
\text { розмежування }\end{array}$ & Елітарна преса & Якісна преса \\
\hline 1. & Періодичність & Місячники & Щоденники, тижневики \\
\hline 2. & Предмет & $\begin{array}{l}\text { Стиль життя, подорожі, мистец- } \\
\text { тво, мода, предмети розкоші }\end{array}$ & Суспільно-політичні проблеми \\
\hline 3. & Аудиторія & $\begin{array}{l}\text { 1. Особи, котрі перебувають на } \\
\text { вершині вертикально організо- } \\
\text { ваних суспільних структур } \\
\text { 2. Особи, що прагнуть до } \\
\text { перцепції елітарних цінностей } \\
\text { попри неналежність до цієї ка- } \\
\text { тегорії суспільства }\end{array}$ & $\begin{array}{l}\text { 1. Включені до політичного } \\
\text { та управлінського життя (полі- } \\
\text { тики, бізнесмени тощо) } \\
\text { 2. Не включені до політич- } \\
\text { ного та управлінського життя: } \\
\text { освічені громадяни }\end{array}$ \\
\hline 4. & Мета & $\begin{array}{l}\text { Орієнтація у вдосконаленні } \\
\text { стилю життя, його наповнення } \\
\text { найкращими благами }\end{array}$ & $\begin{array}{l}\text { Елімінація стану невизначе- } \\
\text { ності }\end{array}$ \\
\hline
\end{tabular}

Висновки. На основі аналізу та синтезу означених наукових положень можна запропонувати визначення елітарної преси та якісної преси. Елітарна преса - це сукупність друкованих 3МI, котрі виходять 3 періодичністю один раз на місяць, висвітлюють в основному питання дозвілля, бізнесу, культури, мистецтва 3 метою удосконалення стилю життя читачів, котрі займають провідне становище в управлінській, інтелектуальній, культурній чи іншій сферах, а також читачів, котрі прагнуть наслідувати елітарний спосіб життя. Якісна преса - сукупність друкованих 3МI, котру складають щоденні та тижневі газети, що відзначаються аналітичністю, неемоційним тоном публікацій, прагнуть до з'ясування глибинної суті явищ, подій суспільної дійсності, уникають сенсаційності, розраховані на високоосвіченого читача, впливають на прийняття управлінських рішень і ставлять собі метою зменшення стану невизначеності читацької аудиторії. Основними параметрами розмежування якісної та елітарної преси слугують періодичність виходу, коло питань, які висвітлюються на їх сторінках, аудиторія і мета. Подальші розвідки у цьому напрямі дозволять збагатити теорію зарубіжної преси новими знаннями та конкретизувати понятійний апарат журналістикознавства. 


\section{REFERENCES}

1. Быков А.Ю. Современная зарубежная журналистика [Електронный ресурс]: конспект лекций/ А.Ю. Быков. - Екатеринбург, 2003 / Доступно 3: https://www.twirpx. $\mathrm{com} /$

2. Житарюк М.Г. Соціокультурна модель журналістики: традиції і новаторство: Монографія/М.Г. Житарюк. - Львів: 2008. - 416 с.

3. Жугай В. Й. Становлення якісної преси у посткомуністичному світі [Електронний ресурс]: автореф. дис. на здобуття наук. ступеня канд. наук із соціальних комунікацій: спец. 10.01.08 «журналістика» / Жугай Віталій Йосипович. - Львів: 2006. - Режим доступу: http://referatu.net.ua/referats/7569/168952

4. Журналістика: словник-довідник/ авт.-укл. І.Л. Михайлин. - Київ: Академвидав, 2013. $-320 \mathrm{c}$.

5. Лось Й.Д. Перспективи світоглядної публіцистики: навчальний посібник/ Й. Д. Лось - Львів: ЛНУ імені Івана Франка, 2014. - 294 с.

6. Корконосенко С.Г. Основы журналистики. Москва: Аспект Пресс, 2004. - 287 с.

7. Ортега-і-Гасет Х. Дегуманізація мистецтва [Електронний ресурс]/X. Ортега-і-Гасет //Вибрані твори; пер. $з$ ісп. О. Товстенко - Київ: Основи, 1994. - 424 с. - Режим доступу: http://ae-lib.org.ua/texts/ortega-y-gaset arte ua.htm.

8. Пірен М.І. Політико-управлінська еліта України: соціо-психологічний аналіз: монографія/М.І. Пірен. - Чернівці: Чернівецький нац. Ун-т, 2013. - 424 с.

9. Попова А.В. Дискурс-картины мира и кортежного взаимодействия элитарных средств информации: докторская диссертация: $04 \mathrm{H} /$ Попова Алена Викторовна. - Вильнюс, 2010.- 200 с.

10.Словник іншомовних слів: тлумачення, словотворення та слововживання [С. П. Бибик, Г. М. Сюта] / ред. С. Я. Срмоленко. - Харків: Прапор, 2012. - 623 с.

11. Смеюха В.В. Теория и практика массовой информации: учеб. пособие / В.В. Смеюха. - Ростов н/Д: ФГБОУ ВПО РГУПС, 2015. - 87 с.

12. Теория культуры: учебное пособие/ В.П. Большаков , И. К. Москвина, С.Н. Иконникова и др.; ред. В.П. Большаков, С.Н.Иконникова. - СПб.: Питер, 2008. -592 с.

13. Типология периодической печати : учеб. пособие для студентов вузов / М. Е. Аникина, В. В. Баранов, О. А. Воронова и др.; ред. М. В. Шкондин, Л. Л. Реснянская. М.: Аспект Пресс, 2009. - 236 с.

14. Черняков Б.I. Зображальна журналістика в газеті, журналі та книзі XVIII-першої половини XIX ст.: текст лекцій / Б.І.Черняков. - К.: Видавничо-поліграфічний центр «Київський університет», 2006. - 215 с.

15. Філософський енциклопедичний словник: довідкове видання / зав. редакцією М. Т.Максименко. - К.: Національна академія наук України. Інститут філософії ім. Г. С. Сковороди, 2002. - 742 с.

16. Hudson F. Journalism in the United States from 1690 to 1872 / F. Hudson. - New York: Harper\&Brothers publishers, 1873. $-812 \mathrm{p}$.

17. Mott F. L. American journalism: a history of newspapers in the United States through 250 years. 1690-1940/F.L.Mott. - New York: The Macmillan Company, 1942. - 813 p.

18. Peterson T. Magazines in the Twentieth Century/T.Peterson. - Urbana: The University of Illinois Press, 1956. -480 p. 
19. Portfolio. The Magazine Of Lifestyles, Interests \& Leisure.URL: www. portfoliomagazinenaples.com/our-story.html.

20. Wood J. P. Magazines in the United States. Their social and economic influence / J. P. Wood. - New York: The Ronald Press Company, 1949. - 328 p.

\title{
TO THE DELINEATION OF THE NOTIONS OF HIGH-QUALITY AND ELITE PRESS (ON THE EXAMPLE OF THE USA)
}

\author{
Natalya Mykhayliv \\ Ivan Franko National University of Lviv, \\ Generala Chuprynky Str., 49, 79044, Lviv, Ukraine \\ e-mail: ozerna.n9@gmail.com
}

In this article on the example of the historical process of formation and modern functioning of the press in the USA an attempt to differentiate between the notions of «elite press» and «high-quality press» have been made, the essence of each of these concepts was clarified, features of «high-quality» and «elite» press were distinguished, as well as the objectives in the use of these concepts, the parameters of the delineation of high-quality and elite press are elaborated and the definitions of each of them are proposed. To this aim, basing on the works of USA scholars the origin of the elite press in the USA was analyzed and it was found that the magazine occupies prominent place in it, basing on the reader's criteria classification of high-quality and elite press is proposed and their common features were revealed.

It was ascertained that the auditory of elite press consists of two parts: first includes highest ranks of the public - ones who try to fulfill their life with elite, status attributes, the second consist of those society members who make efforts to succed the lifestyle of wealthy ones although they do not pertain to the rich. It has been proved that the term «elite», mentioned toward press implies the characteristics of the subject, who sets high demands to the press they read as well as to their activity, rest, etc. In the same time the term «quality press» regards to the object as quality is the key demand to journalistic activity. Quality press is red by politicians and other ones who influence political and business life, as well as by those who has not such a direct influence, but who are interested in this category of topic. All mentioned in the article let us make a conclusion that quality press primarily consists of dailies and weeklies, their typical theme is general political, this category of press is appointed to politicians and intellectuals. Elite press put high demands to its quality, therefore it will not be a mistake to name the elite press as the quality press.

The main parameters for elite and quality press delineation is periodicity, issues that are elucidated on its pages, auditory and aim.

Key words: elite press, quality press, elite, quality, auditory, magazine. 